\title{
Analyzing of Distribution, Standars and Percapita in Urban Green Space (Case Study: Boroujerd City)
}

\section{Hamid reza Saremi', Mohammad Hadiyanpour², Shima Shahverdi ${ }^{3}$}

\author{
${ }^{1}$ Assistance Professor, Department of Art and Architecture, Tarbiyat Modares University, Tehran, Iran \\ ${ }^{2}$ Researcher of $\mathrm{PhD}$ course, Tarbiyat Modares University, Tehran, Iran \\ ${ }^{3}$ M.A Student, Department of Architectural and urbanism, Boroujerd branch, Islamic Azad University, Boroujerd, \\ Iran
}

\begin{abstract}
Green urbanism probably contains the most similar ideas with sustainable urbanism. They both emphasize on urban design with nature, as well as shaping better communities and lifestyles. However, the principles of green urbanism are based on the triple-zero frameworks: zero fossil-fuel energy use, zero waste, and zero emissions. Sustainable Urbanism, on the other hand, is more focused on designing communities that are walk able and transit-served so that people will prefer to meet their daily needs on foot. In this research has been studied urban green space development process in Boroujerd city. Also, the aim of research, is achieving sustainable city. This study is applied and the research method is" descriptive - analytical". Also data collected is documents and field. In order to analyzing of data, was used spearman correlation and Bahram Soltani method .The findings show, percapita of green space isn't well and far from with global standards. So, should be attempted in this issue. At finally was proposed percapita based on Bahram Soltani method.
\end{abstract}

Keyword: Urban Green Space, Percapita, Bahram soltani method, Boroujerd city

\section{1- INTRODUCTION}

To transition from the sanitary city of the twentieth century to the sustainable city of the twenty-first, new knowledge needs to be developed and applied to understanding the role of nature in cities and in supplying the resource requirements for their growth. Cities are, of course, human creations, a big factor in contributing to the drivers of human ecological geochemical change (Vitousek, Mooney, Lubchenco, \& Mellilo, 1997). This review suggests bridging between three distinct research paths concerned with urban areas and nature: urban ecosystem services, urban metabolism and urban political ecology.

New Urbanism inspired Farr's definition of Sustainable Urbanism is based around bringing everything closer together, using higher quality goods, being more efficient, and having everything within walking distance, but Sustainable urbanism closes the loop. The criticism of New Urbanism is that it attempts to apply 19th century urban form to 21 st century cities and that New Urbanism excludes economic diversity by creating expensive places to live that are highly privatized and controlled.

One current articulation of city branding, in line with the increased focus on sustainable development, is the "green" city or environmentally-sustainable city brand. The word green, when used in a marketing sense, encompasses both an environmental policy and biophysical dimension. The environmental policy dimension of green addresses issues of sustainable urban development through a concern for pollution control, reduced carbon dioxide output and limited resource consumption (Kahn, 2006).

The biophysical dimension of green celebrates the green space component of cities, highlighting the important role of urban vegetation in securing a high quality of life (Beatley, 2011). Thus a green city brand can be related to a vision for (1) increased urban environmental political oversight, an ambition to (2) focus on and develop urban biophysical

This article is published under the terms of the Creative Commons Attribution License 4.0

Author(s) retain the copyright of this article. Publication rights with Alkhaer Publications.

Published at: http://www.ijsciences.com/pub/issue/2015-12/

DOI: 10.18483/ijSci.728; Online ISSN: 2305-3925; Print ISSN: 2410-4477 
qualities, or (3) both aspects combined in order to achieve a market advantage.

\section{2- LITERATURE REVIEW}

Since as early as the 1970s, researchers have been experimentally studying the influence of greenery on human attitudes and functioning. One of the main findings - for which a large body of empirical evidence has accumulated - is that natural (i.e. green) environments are consistently preferred over nongreen urban settings, or environments dominated by artifacts (for a review see Ulrich, 1993). Another important observation is that nature can have 'healing' effects on human individuals. One illustrative inquiry in this respect is Ulrich's (1984) Science study, which reports that hospital patients that had undergone a gall-bladder operation recovered more rapidly and felt better when they had views on trees than when they viewed a brick wall from their hospital rooms (Ulrich, 1984). Since Ulrich's pioneering inquiry, many environmental psychology studies have investigated and corroborated the beneficial or 'restorative' effects of vegetative elements (flowers, trees, plants) on human functioning and health

(For reviews Ulrich, 1993; Van den Berg, 2005, 2009). Nowadays this field of inquiry is often referred to as 'Restorative Environments Research' (Van den Berg, 2009). Over the past two decades, two major interpretations of what constitutes a 'restorative experience' have dominated the restorative research literature. One interpretation is termed 'Stress Recovery Theory' (SRT), which has been advanced and elaborated by Roger Ulrich (see Ulrich et al. 1991; for early foundations of SRT see Ulrich, 1983). According to SRT, exposure to unthreatening nature leads to more positively-toned emotional states and is better able to bring physiological arousal in stressed individuals back to more moderate levels than environments devoid of natural elements. SRT has been corroborated by different empirical studies (e.g. Ulrich et al., 1991, 2003; Parsons et al., 1998; Hartig et al., 2003; Custers, 2006; Dijkstra et al., 2008). Quite often, these stress reducing effects are claimed to be rooted in our shared human evolutionary past, during which early humans were deeply dependent on nature for their subsistence and survival (see especially Ulrich, 1993; also Heerwagen and Orians, 1993; Lohr and Pearson-Mims, 2006). In particular, vegetative elements were a source of food and medicine, and offered early humans opportunities for prospect and refuge (e.g. from weather conditions or predators). Ulrich (1993) contends that individuals who genetically retained restorative responses (i.e. stress reduction) toward these natural elements had higher survival chances than those who had not evolved such a hardwired trait. This retention also explains why the stress-reducing effects of (unthreatening) nature are still widespread among modern-world individuals. (Note that greenery also positively impacts behavioral states that are closely related to stress, such as higher frustration tolerance (Cackowski and Nasar, 2003), prolonged pain tolerance (Lohr and Pearson-Mims, 2000), and alleviation of states of anger (Kweon et al., 2008).)

Green spaces are as a complement of urban physical structure. These spaces are a type of urban land-use that has ecologic and social traits. On the other hand, today planning and design is adaption green space networks (leqaee, 1995). Today, urban green spaces are introduced as appropriate method for promotion of life quality due to impressive social and ecological influences (Barker, 1968). So, an urban green space is important issue due to creating beautiful landscape, also it is as obstacle air pollution in cities.

Last years in Iran, don't achieve sustainable cities especially in Tehran metropolitan due to development of cities without regard to infrastructure such as green spaces. In different section of cities exist problems such as air pollution, terrific, shortage of green spaces. Appropriate planning \& effective management in urban green section are necessary for eliminating these problems. Effective management is led to promotion of human life quality in cities. Some countries in world are successful to decline shortage of green spaces by implementing different plans of developing green spaces. The propose of research is, promotion of quality of urban environment.

\section{3- RESEARCH METHOD}

The studied area is 17 of Boroujerd district. Boroujerd is a city in and capital of Boroujerd County, Lorestan Province in western Iran. At the 2006 census, its population was 227,547 in 59,388 families. Among the existing modern cities in Iran, Boroujerd is one of the oldest reported at least since the 9th century. In Sassanid Empire, Boroujerd was a small town and region neighboring Nahavand. Gaining more attention during Great Seljuk Empire in the 9th and 10th centuries, Boroujerd stood as an industrial, commercial and strategic city in Zagros Mountains until the 20th century. In its golden ages, Boroujerd was selected as the state capital of Lorestan and Khuzestan region during Qajar dynasty in the 18th and 19th centuries. Today, Boroujerd is the second largest city of Lorestan; hence, the major industrial, tourist and cultural center of the region. The city has kept its old architecture and lifestyle mostly through mosques, bazaars and houses built in the Qajar era. Boroujerd city is located approximately 1670 meters above sea level and has a moderate climate with cold winters. The highest point is Garrin Mountain $3623 \mathrm{~m}$ above sea level and the lowest area is Gel Rood River in South with 1400 m elevation. Boroujerd Township has $2600 \mathrm{~km}^{2}$ area with approximately 400,000 inhabitants distributed in the city of Oshtorinan and more than 180 villages. 
Boroujerd is located on Silakhor Plain which is the largest agricultural land of Lorestan. The highelevated Zagros Mountains surround it from South East to North West and the peaks are covered with snow most of the times. Rural people work in farms or keep their domestic animals. Other people work in governmental offices, armed forces, factories or small local businesses. The feet of Zagros Mountains is a great destination for nomads and many Lurs and Bakhtiari nomads move there in summer. The area is paved with highways and is a crossroad between Tehran and Khuzestan Province as well as Isfahan Province and Kermanshah Province.

This research is applied. Research method is "descriptive - analytical". At first, was studied area of green space between seventeen districts. In order to analyzing data was used Bahram Soltani method. Prof. Bahram Soltani has been proposed method for determining percapita based on environmental condition each area. Also, was used from Spearman correlation and $\mathrm{T}$-Test method in order to considering relation between valuables ( green space and population ).

\section{4- DATA ANALYZE}

\section{4-1-Descriptive statistic}

Per capita of green space is difference between cities according to its climate, location and geographical position. Table 1 compare per capita of green space between cities and various countries.

\begin{tabular}{|c|c|c|c|c|c|}
\hline Standard & Per capita & City & Standard & $\begin{array}{c}\text { Per } \\
\text { capita }\end{array}$ & City \\
\hline $12-7$ & 14.8 & Borujerd & 50 & 50 & Los Angeles \\
\hline $12-7$ & 23 & Isfahan & 50 & 117 & Boston \\
\hline $12-7$ & 10.1 & Tabriz & $60-30$ & 40 & Berlin \\
\hline
\end{tabular}

Table 1: per capita of green space in different cities in world

Based on table 1, there are 17 districts in boroujerd city. Also, per capita of it are 14.8. This number is appropriate with comparison other cities, but it is far from world standard. There is various standard in word. Figure 1 shows them.

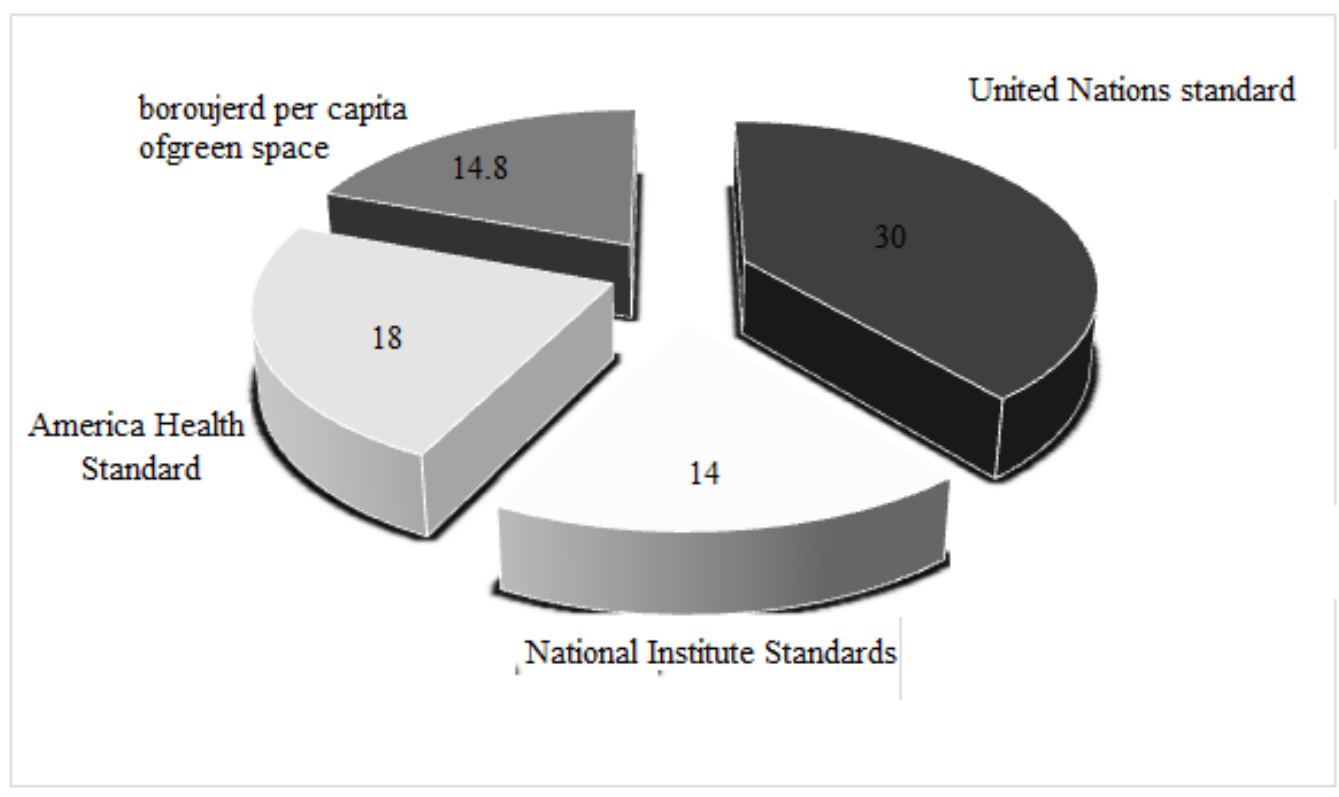

Figure 1: difference standard (standard are $\mathbf{m}^{2}$ )

So, according to figure 1 per capita of green space in studied area with comparison other standard is low. Table 2 , shows distribution of parks and green area in Boroujerd city. 


\begin{tabular}{|c|c|c|}
\hline & Item & area \\
\hline 1 & park & 2600503 \\
\hline 2 & Squares & 235943 \\
\hline 3 & Boulevard & 373234 \\
\hline 4 & Margins & 219078 \\
\hline 5 & Production centers of trees & 79542 \\
\hline 6 & Planted street & 951700 \\
\hline 7 & Private green space & 296000 \\
\hline \multicolumn{2}{|c|}{ Total } & 4756000 \\
\hline
\end{tabular}

Table 2: distribution of urban green area in Boroujerd city (Source: parks \& green space organization)

One of the main effects of urban green space is social benefits. Open green spaces of the community and the public are at their leisure, and meetings with friends social and cultural (Qorbani \& Timurid, 2010: $48)$, the squares, boulevards, trees, green space agencies respond is not this need be a human being, so we offer to provide green space in proportion to the population, climatic and environmental features are Boroujerd. Table 3 shows area of urban green space in each district.

\begin{tabular}{|c|c|c|c|c|c|}
\hline 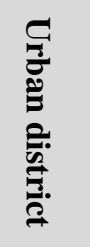 & 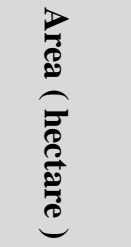 & 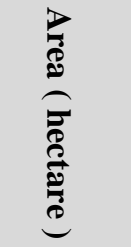 & 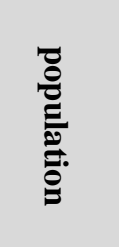 & 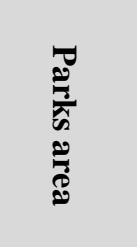 & 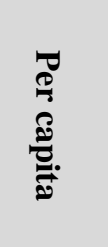 \\
\hline 1 & 174.35 & 174.35 & 41870 & 32130 & 0.76 \\
\hline 2 & 144.55 & 144.55 & 26182 & 60870 & 2.32 \\
\hline 3 & 257.09 & 257.09 & 55495 & 61764 & 1.11 \\
\hline 4 & 127.01 & 127.01 & 34585 & 44862 & 1.29 \\
\hline 5 & 123.50 & 123.50 & 20333 & 106696 & 5.24 \\
\hline 6 & 175.73 & 175.73 & 46913 & 150200 & 3.20 \\
\hline 7 & 337.34 & 337.34 & 41440 & 200932 & 4.84 \\
\hline 8 & 326.80 & 326.80 & 28248 & 610932 & 21.62 \\
\hline 9 & 188.24 & 188.24 & 10352 & 66450 & 6.41 \\
\hline 10 & 114.34 & 114.34 & 2342 & 88445 & 37.76 \\
\hline 11 & 216.81 & 216.81 & 0 & 0 & 0 \\
\hline 12 & 182.77 & 182.77 & 817 & 48500 & 59.36 \\
\hline 13 & 52.34 & 52.34 & 1311 & 20515 & 15.64 \\
\hline 14 & 204.38 & 204.38 & 1312 & 60000 & 45.73 \\
\hline 15 & 201.89 & 201.89 & 4759 & 978207 & 205.54 \\
\hline 16 & 199.16 & 199.16 & 2611 & 0 & 0 \\
\hline 17 & 488.15 & 488.15 & 430 & 70000 & 162,72 \\
\hline Total & 3514.49 & 3514.49 & 320000 & 2600503 & 38.24 \\
\hline
\end{tabular}

Table 3: distribution of green space in 17 district of Boroujerd city

Source: parks \& green space organization 
Based on table 3, distribution of urban green space is not appropriate. For example, some districts are central (1-7 \& 9). So, citizen need urban green space mere than other areas. But there isn't it. Thus, there is balance between districts ( figure 2).

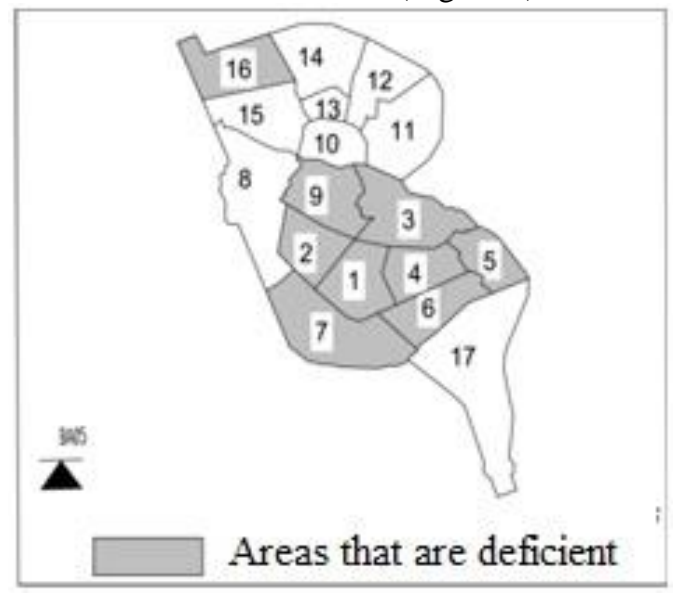

Figure 2: inappropriate distribution of green space

\section{4-2- Inferential statistics}

In part of paper, was analyzed data by T-Test. In order to, evaluation of relationship between the population and the rate of green space areas of the seventeen districts of Boroujerd city.

According to assessments made capita green space in the city during the last two decades has had a relatively better growth, but still more areas of the city, far from achieving a comprehensive and detailed plan of the proposed per capita equal to the lowest standard of Ministry of housing and Urban Development, the 7 square meters per person there. The other half of the per capita green area of green space park. Although non-park green space in urban air and television are effective but do not have much value in terms of social functioning and mental health. Therefore, the actual green space per capita (per capita park) is 8.1 square meters. So, in order to better assessment, was calculated T-Test. also, was calculated T-Test by 4 degrees of freedom, significant level of 0.001 , higher than the $95 \%$ confidence

\begin{tabular}{|c|c|c|c|c|c|c|}
\hline & \multicolumn{6}{|c|}{ Test Value $=0$} \\
\cline { 2 - 7 } & $\mathrm{t}$ & $\mathrm{df}$ & Sig. (2-tailed) & $\begin{array}{c}\text { Mean } \\
\text { Difference }\end{array}$ & $\begin{array}{c}\text { 95\% Confidence Interval } \\
\text { of the Difference }\end{array}$ \\
\hline Population & 3.994 & 16 & 0.001 & 18764.7059 & 8804.567 & 28724.845 \\
\hline $\begin{array}{c}\text { the rate of green } \\
\text { space areas }\end{array}$ & 3.994 & 16 & 0.001 & 18764.7059 & 8804.567 & 28724.845 \\
\hline
\end{tabular}

Table 4: evaluation of relationship between the population and the rate of green space areas of the seventeen districts of Boroujerd city

According to table 4 , there is significant difference between population and the rate of green space areas of the seventeen districts of Boroujerd city.it means, there isn't adaptability between seventeen districts population average and Average rate of green space.

\section{Hypothesis test}

H0: there isn't significant relationship between population and rate of green space.
H1: there is significant relationship between population and rate of green space.

If significant level ( $\mathrm{sig}$ ) is greater than 0.05 has been concluded H0 .Also, if significant level (sig) is less than 0.05 has been concluded $\mathrm{H} 1$.

According table 5, has been calculated significant level is 0.171 ( $\mathrm{sig}=0.171)$. It is greater than 0.05 . So to be confirmed $\mathrm{H} 0$.

\begin{tabular}{|c|c|c|c|c|}
\hline & & & Population & Green space \\
\hline \multirow{6}{*}{$\begin{array}{l}\text { Spearman's } \\
\text { correlation }\end{array}$} & \multirow{3}{*}{ Population } & Correlation Coefficient & 0.0001 & 0.348 \\
\hline & & Sig. (2-tailed) & 0 & 0.171 \\
\hline & & $\mathrm{N}$ & 0.17 & 0.17 \\
\hline & \multirow{3}{*}{ Green space } & Correlation Coefficient & 0.348 & 0.0001 \\
\hline & & Sig. (2-tailed) & 0.171 & 0 \\
\hline & & $\mathrm{N}$ & 0.17 & 0.17 \\
\hline
\end{tabular}

Table 5: Spearman correlation between population and green space 
The result of test shows inappropriate distribution of green space in Boroujerd city.

\section{4-3- Bahram Soltani method}

There are indicators in order to calculating urban green space per capita. The concept of green space can only be used for green space for leisure, play and recreation (Por Ahmad, 2010: 37).Prof .Kambiz
Bahram Soltani has proposed the method for calculating green space per capita in Iran cities. In this research was used mentioned method.

Therefore was considered the average temperature in the warmest month of the year as climate characterize. In table 6 is considered the range of heat proportional in Iran and for each of them is assigned a factor.

\begin{tabular}{|c|c|c|}
\hline Temperature & coefficient & Explanation \\
\hline $25>$ & 1 & Too appropriate \\
\hline $25-30$ & 2 & Appropriate \\
\hline $30-35$ & 3 & acceptable \\
\hline $35-40$ & 4 & inappropriate \\
\hline $40<$ & 5 & $\begin{array}{c}\text { Too } \\
\text { inappropriate }\end{array}$ \\
\hline
\end{tabular}

Table 6: determining coefficient of green space according temperature (Source: Kambiz Bahram Soltani, 1996: 96)

\begin{tabular}{|c|c|c|}
\hline Explanation & Coefficient & Environment qualify \\
\hline There isn't air and nose pollution & 0 & Too appropriate \\
\hline There is air pollution and nose pollution in daily time & 1 & appropriate \\
\hline There is nose pollution in hour a days & 2 & Inappropriate \\
\hline There is air ad nose pollution in all of time & 3 & Too inappropriate \\
\hline
\end{tabular}

The average of temperature in Boroujerd city is 28.8 , so the coefficient of green space is 2 . After that, should be determined environment qualify. In order to calculating this item, was studied two factors. There are air and nose pollution (table6).

Table 7: Environments qualify and green space coefficient Source: Kambiz Bahram Soltani, 1996

In order to assessing air quality was used PSI indicators.

\begin{tabular}{|c|c|c|}
\hline Environment quality & $\begin{array}{c}\text { The number } \\
\text { of day }\end{array}$ & $\begin{array}{c}\text { Standard indicator } \\
\text { PSI }\end{array}$ \\
\hline Clean & 29 & $0-50$ \\
\hline Healthy & 71 & $50-100$ \\
\hline Unhealthy for special groups & 44 & $100-200$ \\
\hline Too unhealthy & 34 & $200-250$ \\
\hline Dangerous & 2 & $>250$ \\
\hline
\end{tabular}

Table 8: Measuring air pollution standards based on PSI Source: environment organization

Thus according data collected the PSI in Boroujerd is 50-100 (71 days). At finally indicator in Bahram Soltani method is social factors in calculating per capita. It is number of people living in the rooms of a residential unit (Density people / room).

\begin{tabular}{|c|c|c|}
\hline Coefficient & Quality & Density people / room \\
\hline 0 & Appropriate & 1 person / room \\
\hline 1 & Inappropriate & 2 person /room \\
\hline 2 & Too inappropriate & 3 person /room \\
\hline
\end{tabular}

Table 9: Quality residential units and Coefficient of green space Source: Kambiz Bahram Soltani, 1996 
In studied area the average of room is 2.9 (Iran Statistical Center, 2012). So, Coefficient of green space based on density people in room is 1 . At finally was used from Bahram Soltani formulate. It is:

$$
\sum Q=\times Q(\operatorname{tmax})+Q(e q)+Q\left(\frac{p}{r}\right)
$$

In this formula:

$Q(\operatorname{tmax})$ (average of maximum temperature) $=2$ $Q(e q)$ coefficient $=1$

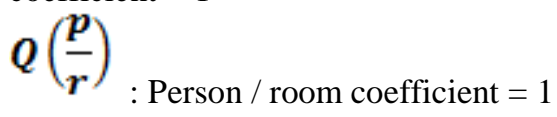

Proposed percapita $=\sum(2+1+1) \times 7=28$

Therefore, proposed per capita according mentioned method is $28 \mathrm{~m}^{2}$ for each person. Also, the area of green space is 4756000 now, based on percapita there is 4204000 shortages. On the other hand, proposed green space area is 8960000 .

\section{CONCLUSION}

Today, human need peace in every condition. The main propose of urban green spaces is their social effects, also creating relation between human and nature. Urban green spaces have important effects in human life such as: improving residential environment, preventing of air pollutions and etc. Urban green space, create balance between building and natural systems; also it is appropriate place for leisure time in our cities.

Public land uses in many cities especially urban green spaces aren't successful due to some factors such as: high population density, imbalance in land use location, neglect to redial access for providing services and etc. Today, it isn't enough that we increase service centers also effort to achieve the standard and urban per capita because it is possible that all citizen haven't appropriate access to land use (parks \& urban green space) due to imbalance of their location. Due to urbanism phenomenon grow sharply, so analyzing of appropriate location and its geographical distribution is very useful in development and future of cities.

Two big challenges exist to approaching cities as complex systems. One is that of nature. The shift to acknowledging that cities have their own novel nature - one that humans have had an important impact in creating - seems essential for urban ecosystem science. And beyond that, recognizing that the built environment of cities is nature too, transformed, made from inert substances like sand or minerals, but ultimately resourced from the Earth, is critical to linking the city to hinterlands and to natural processes. Such a view of cities, as a kind of reconstructed nature, may impact how ecology is done in the city, and accounting of the metabolic footprint of urban areas.

\section{References}

1. Barker, R.G. 1968. Ecological Psychology, Stanford Ca: Stanford University Press.

2. Balram, Sh and Dragicevic, S (2005); Attitudes Toward Urban Green Space: Integrating Guestionnaire Survey and Collaborative GIS Techniques to Improve Attitude Measurements, Iandscape and Urban Planing journal 75 : $167-17$

3. Beatley, T., 2011. Biophilic Cities: Integrating Nature into Urban Design and Planning. Island Press, Washington, D.C.

4. Cackowski, J.-M., Nasar, J.L., 2003. The restorative effects of roadside vegetation. Implications for automobile driver anger and frustration. Environment and Behavior 35, 736751 .

5. Chiesura. A(2004), The Role of Urban Parks for the Sustain city, Iandscape and Urban Planing journal 68 : 129-1382

6. Chace, J.F., Walsh, J.J.,(2006). Urban effects on native avifauna: ,Iandscape and Urban Planing journal74 : 46-69

7. Qorbani, Rasol and Timurid, R. (2010) Analysis of the parks' role in improving the quality of urban life by using the pattern Seeking-Escaping Case Study: Park in the city of Tabriz, Human Geography Research, No. 72, Ss62-47.

8. Heerwagen, J.H., Orians, G.H., 1993. Humans, habitats, and aesthetics. In: Kellert, S.R., Wilson, E.O. (Eds.), The Biophilia Hypothesis. Island Press, Washington, pp. 138172.

9. Leqaee (1995): planning urban green space, no5\&6

10. Lohr, V.I., Pearson-Mims, C.H., 2006. Responses to scenes with spreading rounded, and conical tree forms. Environment and Behavior 38, 667-688.

11. Lohr, V.I., Pearson-Mims, C.H., 2000. Physical discomfort may be reduced in the presence of interior plants. HortTechnology 10, 53-58.

12. Kahn, M., 2006. Green Cities: Urban Growth and the Environment. Brookings Institution Press, Washington, D.C.

13. Pour Ahmed, Ahmed, Akbar Pvrsraskanrvd, Muhammad. Sotoudeh, S. (1388) 9 management of urban green space area of Tehran, Human Geography Research Quarterly, No. 69, Ss50-29.

14. Stanners, D., Bourdeau, p.,(1995).The Urban Environment. In:Stanners,D.,Bourdea

15. Kweon, B.-S., Ulrich, R.S., Walker, V.D., Tassinary, L.G., 2008. Anger and stress: the role of landscape posters in an office setting. Environment and Behavior 40, 355-381.

16. Ulrich, R.S., 1984. View through a window may influence recovery from surgery. Science $224,420-421$.

17. Ulrich, R.S., 1993. Biophilia, biophobia, and natural landscapes. In: Kellert, S.R., Wilson, E.O. (Eds.), the Biophilia Hypothesis. Island Press, Washington, pp. 73-137.

18. Ulrich, R.S., Simons, R.F., Miles, M.A., 2003. Effects of environmental simulations and television on blood donor stress. Journal of Architectural \& Planning Research 20, 3847.

19. Ulrich, R.S., Simons, R.F., Losito, B.D., Fiorito, E., Miles, M.A., Zelson, M., 1991. Stress Recovery during exposure to natural and urban environments. Journal of Environmental Psychology 11, 201-230.

20. Van den Berg, A.E., 2009. Restorative effects of nature: towards a neurobiological approach. In: Louts, T., Reitenbach, M., Molenbroek, J. (Eds.), Human Diversity, Design for Life. In: Proceedings of the Ninth International Congress of Physiological Anthropology, 22-26 August, Delft, the Netherlands. Faculty of Industrial Design Engineering, Delft University of Technology, Delft, pp. 132138. 